\title{
Performance effects of entrepreneurial orientation, strategic intent and absorptive capacity within coopetitive relationships
}

DOI:

10.1108/IJOPM-06-2020-0376

\section{Document Version}

Accepted author manuscript

Link to publication record in Manchester Research Explorer

Citation for published version (APA):

Seepana, C., Huq, F., \& Paulraj, A. (2021). Performance effects of entrepreneurial orientation, strategic intent and absorptive capacity within coopetitive relationships. International Journal of Operations and Production Management . https://doi.org/10.1108/IJOPM-06-2020-0376

Published in:

International Journal of Operations and Production Management

\section{Citing this paper}

Please note that where the full-text provided on Manchester Research Explorer is the Author Accepted Manuscript or Proof version this may differ from the final Published version. If citing, it is advised that you check and use the publisher's definitive version.

\section{General rights}

Copyright and moral rights for the publications made accessible in the Research Explorer are retained by the authors and/or other copyright owners and it is a condition of accessing publications that users recognise and abide by the legal requirements associated with these rights.

\section{Takedown policy}

If you believe that this document breaches copyright please refer to the University of Manchester's Takedown Procedures [http://man.ac.uk/04Y6Bo] or contact uml.scholarlycommunications@manchester.ac.uk providing relevant details, so we can investigate your claim.

\section{OPEN ACCESS}




\title{
Performance effects of entrepreneurial orientation, strategic intent, and absorptive capacity within coopetitive relationships
}

\begin{abstract}
Purpose: While the significance of organizational resources and capabilities is widely discussed, little is known about their interrelationships as well as benefits for firms that are involved in coopetitive relationships. Against this backdrop, we aspire to investigate the performance effects of entrepreneurial orientation, strategic intent, and potential absorptive capacity as well as their complementarity effects on operational and innovation performance for firms involved in horizontal coopetitive relationships.
\end{abstract}

Design/methodology/approach: Drawing upon the resource-based-view, dynamic capabilities, and the relational view theories, this study forwards numerous hypotheses between the constructs of interest. The proposed hypotheses are tested utilizing survey data collected from 313 horizontal coopetitive relationships.

Findings: Our results clearly suggest that entrepreneurial orientation, strategic intent, and potential absorptive capacity could positively impact innovation and operational performance outcomes independently. Additionally, we also find strategic intent and potential absorptive capacity to have differential moderating effects on the relationships between entrepreneurial orientation and the performance outcomes.

Originality: The findings suggest that although strategic intent and potential absorptive capacity could lead to performance benefits independently, when it comes to coopetitive relationships, the use of both these capabilities may not substantially increase the positive impact of entrepreneurial orientation on performance outcomes. Specifically, given that these capabilities could intensify competitiveness as well as hostility between partners, they seem to affect the firm's performance differently.

Keywords: Entrepreneurial orientation; Strategic intent; Absorptive capacity; Innovation performance; Operational performance; Coopetition.

Paper type: Research paper 


\section{INTRODUCTION}

Coopetition - a phenomena of collaboration between competitor firms, is argued to assist firms in improving competitive advantage (Li et al., 2011, Gnyawali and Park, 2011, Hoffmann et al., 2018). Extant coopetition literature attributes this competitive advantage to various performance benefits that coopetitors (firms that pursue coopetition) could attain by utilizing different organizational resources and capabilities (Ritala and Hurmelinna-Laukkanen, 2013, Wilhelm and Sydow, 2018). Similarly, operations management studies also attribute competitive advantage to the deft combinations of different set of capabilities and resources that are available to a firm (Patel et al., 2015, Raddats et al., 2017). Although the significance of coopetitors' resources and capabilities is generally comprehensible, our understanding about the various firm-specific key resources and capabilities as well as their effects on a firm's performance within coopetition relationships still remains nascent.

Coopetitors tend to possess various traditional resources and capabilities such as knowledge (Ritala and Hurmelinna-Laukkanen, 2009, Gnyawali and Charleton, 2018), technological capabilities (Gnyawali and Park, 2011, Bouncken et al., 2016), relational investments (Gnyawali and Park, 2011), and ambidextrous managers (Bengtsson et al., 2016, Seepana et al., 2020). The significance of such resources and capabilities and how they could contribute to coopetitors competitive advantage is debated in extant literature by often referring to the real-world example of the Sony-Samsung horizontal coopetition relationship (Gnyawali and Park, 2011, Bouncken and Fredrich, 2016); Sony-Samsung coopetition resulted in the development of new generation television display panels (Gnyawali and Park, 2011). Nevertheless, coopetition is complex and competitive in nature mainly due to the simultaneity of cooperation and competition within the relationship and due to the fact that the coopetitive firms need similar resources, operate in similar industries and target similar markets (Ritala and Hurmelinna-Laukkanen, 2009, Gnyawali and Charleton, 2018). 
The complex nature of coopetition could imply that the coopetitors also possess aggressive and strategic firm-specific resources and capabilities to sustain their competitive advantage; however, such firm-specific characteristics have not received adequate attention in extant research. For instance, high-levels of entrepreneurial orientation (EO) appears to be an integral characteristic of coopetitors ( $\mathrm{Li}$ et al., 2011) which extant literature views as an intangible strategic resource (Atuahene-Gima and Ko, 2001, Kickul et al., 2011). Both Samsung and Sony are said to be highly entrepreneurially oriented (Lee and Slater, 2007, Paek and Lee, 2018). High-levels of EO could be reflected in a firm's strong emphasis on research and development (R\&D), innovation, and pursuing high-risk ventures (Lumpkin and Dess, 1996, Ireland et al., 2001); this is quite evident in the cases of Sony and Samsung. Apart from EO, coopetitors could also possess an aggressive strategic intent (SI) (Luo, 2007, Seepana et al., 2020). Strategic intent can guide firms to channel their resources in the right direction to attain strategic goals (Hamel and Prahalad, 1989). For example, the strategic intent of Samsung is said to have assisted its resources, capabilities, and learning from competitors that eventually enabled it to improve production efficiencies (Hitt et al., 1995). SI has been viewed as a strategic capability that coopetitors could possess (Seepana et al., 2020). Furthermore, coopetitors also tend to possess high-levels of potential absorptive capacity (PAC) which can be utilized to capture external knowledge and use such knowledge for their own benefits (Ritala and Hurmelinna-Laukkanen, 2013). These characteristics can also be noticed in other firms such as Apple and Google that pursued coopetition relationships (Luo, 2007, Bouncken and Fredrich, 2016) - Apple's EO (Covin and Lumpkin, 2011) and SI (Mantere and Sillince, 2007) are argued to be crucial for its competitiveness. Similarly, Google is said to have pursued EO to advance its competitive advantage (Chang et al., 2019). Overall, these examples clarify that coopetitors are likely to possess as well as attribute significant importance to EO, SI, and PAC. 
Extant literature generally indicates that EO (Handfield et al., 2009, Sahi et al., 2019), SI (Luo, 2007, Mariadoss et al., 2014), and PAC (Fosfuri and Tribó, 2008) can lead to superior performance benefits. However, as much as these resources and capabilities have the potential to deliver performance benefits on their own, they may also complement each other to further advance the performance benefits. The notions from the resource-based view (RBV) and dynamic capabilities suggest that a firm's resources tend to be reshaped/reconfigured/redeployed when complemented by its capabilities (Helfat et al., 2007, Mitrega et al., 2017), thereby leading to competitive advantage. Alternatively, relational view also indicates that firms' resources and capabilities complement each other in relationalsettings to benefit their competitive advantage (Dyer and Kale, 2007). Accordingly, EO as a resource is likely to be complemented by the capabilities of SI and PAC; incidentally, both SI (Mariadoss et al., 2014) and PAC (Fosfuri and Tribó, 2008) are viewed to have abilities to reconfigure resources to generate better performance. However, given that this line of thought lacks evidence, it is important to examine the effects of these distinct capabilities and resources considering the degree of significance attached to them in terms of their potential complementarity as well as performance benefits within the context of coopetition. Therefore, our study is based on the following two research questions - (1) How do EO, SI and PAC affect a firm's performance within a coopetition relationship? and (2) How does the complementarity of SI and PAC affect the relationship between EO and performance?

As for performance benefits, innovation (incremental and radical) and operational performance (efficiencies, flexibility, etc.,) are often presented to be the benefits that firms could attain in coopetitive relationships using the firms' resources and capabilities that contribute to their competitive advantage (Luo, 2007, Gnyawali and Park, 2011, Hoffmann et al., 2018). Operations management (OM) studies also attribute innovation and operational outcomes to contribute to firms' competitive advantage (Handfield et al., 2009, Jinhui Wu et 
al., 2012). Likewise, both the relational view and dynamic capabilities theory advocate innovation and operational outcomes as important performance variables to affect firms competitive advantage (Dyer and Kale, 2007, Mitrega et al., 2017). Given the general consensus between extant literature as well as theoretical anchors on the significance of innovation and operational performance, this study choses to examine the possible effects of EO, SI, and PAC as well as their complementarity on these outcomes. In this study, the performance outcomes are focused on the relationship, and not limited to a focal firm.

Our study makes significant contributions to extant literature. First, to the best of our knowledge, this study is the first to investigate the performance effects of a firm's EO, SI, and PAC on the firm's operational and innovation performance within the context of horizontal coopetitive relationships. Although studies such as Ritala and Hurmelinna-Laukkanen (2013) suggest a link between PAC and innovation, it is unknown whether such performance benefits prevail when PAC interacts with other equally important resources and capabilities (in our case, EO and SI). Accordingly, our study contributes to extant literature in that it validates the positive performance effects of all three firm-level characteristics, i.e., EO, SI, and PAC.

Second, the findings pertaining to the moderating effect of both PAC and SI contribute to the research that seeks to explore (1) the use of interactive capabilities in relationships (Covin et al., 2006, Raddats et al., 2017), and (2) firm-level capabilities that could assist coopetitors to be successful (Bouncken and Fredrich, 2016, Gnyawali and Charleton, 2018). Even though firm-level capabilities as the moderators on the associations between EO and various outcomes is generally considered to be certain (Covin et al., 2006, Engelen et al., 2014), our results clearly suggest that this conjecture need not be true when it comes to firms involved in horizontal coopetitive relationships. In fact, our results pertaining to the moderating effect of SI and PAC seem to be counterintuitive to current belief and suggest that there might be an "icarus paradox" at play. Specifically, when it comes to the combined effects of EO, SI, and PAC, having all 
three might indicate "too much of a good thing" and end up being detrimental to coopetitors. In this study, "too much of a good thing" refers to the extent of resources and capabilities that might offer firms success independently while becoming overwhelming when combined together (Busse et al., 2016). In other words, higher levels of such resource and capability combinations (EO, SI, PAC in our case) could lead to failures instead.

Finally, our study adds to OM calls for cross-disciplinary research between OM and entrepreneurship (Kickul et al., 2011, Sahi et al., 2019) as well as OM and strategic management concepts (Hitt, 2011). Specifically, we combine EO (entrepreneurship literature), SI and PAC (strategic management concepts) with innovation and operational performance. The contributions also add to OM studies that seek to explore coopetitors' organizational capabilities (Wilhelm and Sydow, 2018), and their interaction effects (Li et al., 2011).

\section{THEORETICAL BACKGROUND AND HYPOTHESIS DEVELOPMENT}

\subsection{Entrepreneurial orientation}

EO refers to a set of practices and processes that drive a firm's pursuit of entrepreneurial activities (Covin and Lumpkin, 2011). It is widely addressed using three characteristics - either an aggregate measure comprising 'innovation, aggressiveness, and risk-taking' (Li et al., 2017, Wales et al., 2011) or comprising 'aggressiveness, risk-taking, and proactiveness' (AtuaheneGima and Ko, 2001). Firms in general, no matter whether they engage in coopetition or not, involve in implementing EO (Wales et al., 2011). When it comes to coopetition in particular, high levels of EO appears to be an integral part of coopetitors as it can be noticed from the characteristics of such firms - e.g. Sony and Samsung (Lumpkin and Dess, 1996, Lee and Slater, 2007, Paek and Lee, 2018). The rationale for firms to choose partners with high EO can be attributed to their propensity for being proactive, aggressive, innovative, risk-taking, and autonomous, which can help firms to cope with the changing environment (Lumpkin and Dess, 1996) as well as to attain potential performance benefits (Bouncken et al., 2016). 
The tenets of RBV and its extension, the dynamic capabilities view, assert that firms tend to attain competitive advantage through valuable, rare, inimitable, and non-substitutable resources (VRIN) (Barney, 1991, Teece et al., 1997). However, possession of VRIN resources alone would not sustain a firm's competitive advantage. It requires continuous efforts from the firm to adapt and upgrade VRIN resources so as to keep them distinctive from market competition (Teece et al., 1997, Eisenhardt and Martin, 2000). Consistent with these theories, a firm's EO represents a valuable, rare, and inimitable organized gestalt through which the firm will be able to generate competitive advantage (Wiklund and Shepherd, 2005, Anderson and Eshima, 2013). Besides, EO can facilitate structuring, upgrading, and leveraging all of a firm's resources towards attaining the firm's objective of performance benefits (Anderson and Eshima, 2013). Furthermore, such resource structuring among the entrepreneurial firms could potentially pave the way to create new combinations of products or processes through leveraging existing and externally obtained resources (Teng, 2007). Thus, EO can be argued to contribute to product/process innovations and other performance outcomes.

In the context of strategic relationships, RBV indicates EO to be an intangible resource that is embedded in organizational routines and distributed across an organization as well as its partners (Li et al., 2017, Anderson and Eshima, 2013). These entrepreneurial firms possess dissimilar complementary resources and consistently aspire to access such resources of other entrepreneurial firms (Teng, 2007). The aggressive and risk-taking nature of EO specifically strengthens firms' ability to access necessary resources from their partners (Li et al., 2017, Teng, 2007) and utilize them for novel inventions. In other words, highly entrepreneurial firms are in constant search for new information and are keen to engage in relationships to tap entrepreneurial knowledge and utilize it to develop product/process innovations. Additionally, these firms' propensity for R\&D investments as well as pursuing high-risk projects is likely to further fuel their innovations (Jiang et al., 2016). 
Alternatively, the entrepreneurial knowledge exchanges as well as R\&D between entrepreneurial partners can also assist to leverage their operational competencies (Handfield et al., 2009, Kickul et al., 2011). The interactions between entrepreneurial partners can create significant synergies between their operations (Handfield et al., 2009) which can improve operational outcomes. Therefore, EO potentially could lead to both innovation and operational performance benefits. Accordingly;

$\mathrm{H}_{1}$ : Entrepreneurial orientation has a positive effect on both operational and innovation performance.

\subsection{Strategic intent}

A firm's strategic intent refers to its ambition to win marketplaces and competitive dominance by creating synergies between the firm's supply chain relationships, resource stocks and capabilities, and strategic goals (Hamel and Prahalad, 1989, Han et al., 2018). It assesses the firm's ambitions and consequently acts by deliberately mobilizing all of the firm's energy towards attaining those ambitions (Johnson and Sohi, 2001). One of the important acts of strategic intent that lead the firm to attain its ambitions involves investing outside the firm's boundaries (Deng, 2004, Gnyawali and Charleton, 2018); this also includes striking up relationships with competitors (Hamel et al., 1989) so as to enhance firm-level capabilities and maximize performance (Deng, 2004, Rui and Yip, 2008).

The dynamic capabilities theory asserts that capabilities are built within a firm rather than being bought from markets, therefore, they are very much integral as well as embedded within the firm (Eisenhardt and Martin, 2000, Helfat et al., 2007). It is due to the fact that dynamic capabilities rely on the firm's extensive learning processes that include learning from within by utilizing the firm's experiences, resources, internal and external relationships, and skills etc (Dyer and Kale, 2007). These learning processes allow the firm to sense and seize opportunities, combine, enhance and when necessary reconfigure both the tangible and 
intangible assets that are at the firm's disposal in order to sustain its competitive advantage (Helfat et al., 2007).

Consistent with the dynamic capabilities tenets, strategic intent can operate as a dynamic capability and serve as an anchor to sense opportunities and channel resource allocation decisions, directing alliance arrangements, and eventually shows direction for firms to realize their various performance objectives (Mariadoss et al., 2014, Koza and Lewin, 2000). When pursuing interorganizational relationships, a firm's SI often translates into a collaborative learning intent (Lawson and Potter, 2012). Such a learning intent likely paves the way for alignments between the partners' intent as well as strategies and further advances the realization of the firm's intent through acquisition and garnering of resources for the development of valuable outcomes (Mariadoss et al., 2014). Specifically, strategic intent's ambitious objectives of market and/or strategic dominance provides the impetus for firms to pursue joint research and product development with an ambition to acquire necessary information, resources and capabilities to support the developments (Koza and Lewin, 2000) associated to potential innovation generations.

Performance optimization particularly is paramount for the attainment of strategic intent's objectives (Rui and Yip, 2008). Given that strategic intent can also be an enabler to a firm's operational strategy formation and it is communicated and integrated across the firm's hierarchies, strategic intent could play a fundamental role in setting up operational priorities to influence the firm's operational practices and decisions (Contiero et al., 2016). Nevertheless, improving and sustaining competitiveness of the firm through operational goals such as increased efficiencies holds one of the central priorities for firms with strong strategic intents (McAdam et al., 2014). Therefore, strategic intent guided operational practices that underpin the operational priorities can subsequently assist firms to achieve operational efficiencies and flexible operations (Shin et al., 2015). In other words, intent to gain competitive advantage 
through identifying opportunities, learning, as well as gathering and building resource combinations would result in improved innovation and operational benefits. Therefore;

$\mathrm{H}_{2}$ : Strategic intent has a positive effect on both operational and innovation performance.

\subsection{Potential absorptive capacity}

The significance of absorptive capacity in coopetitive relationships is widely acknowledged in extant literature (Cepeda-Carrion et al., 2012, Ritala and Hurmelinna-Laukkanen, 2009). The broader scope of the absorptive capacity is explained dichotomously - 'potential absorptive capacity' and 'realized absorptive capacity' (Zahra and George, 2002). The former refers to the capacity of a firm to "acquire and assimilate knowledge and resources externally", whereas the latter refers to the capacity of a firm to "leverage the absorbed knowledge and exploit it for performance benefits" (Zahra and George, 2002). Accordingly, potential and realized capacities are essentially different concepts as the former requires change, flexibility, and creativity whereas the latter seeks control, order, and stability (Cepeda-Carrion et al., 2012). Given our ambition is to study the benefits gained from coopetitive activities, the study focuses on PAC to reflect on the potential effectiveness as well as the ways in which external knowledge could be utilized by a firm using its coopetitive relationship. In doing so, we follow the work of Ritala and Hurmelinna-Laukkanen (2013) which suggests that focusing on the potential-side of absorptive capacity as opposed to realised absorptive capacity would allow to examine coopetitors potential value creating resources and capabilities more precisely.

The dynamic capabilities theory envisions absorptive capacity to be an important capability to advance competitive advantage of firms given its ability to foster organizational change through redefining and redeploying the firm's knowledge resources (Todorova and Durisin, 2007). Dynamic capabilities could be envisioned as a set of routines that influence a firm's ability to create, reconfigure, and redeploy organizational resources and capabilities to 
advance competitive advantage (Zahra and George, 2002). When it comes to interfirm relationships, the greater availability of external knowledge (from partner) enables the dynamic capabilities to advance the ability of a firm to absorb as well as redeploy necessary knowledge to feed internal objectives of innovation and other performance outcomes (Fosfuri and Tribó, 2008). Nevertheless, this ability to recognize the significance of the potential value that new knowledge could bring in itself makes potential absorptive capacity a key building block of dynamic capabilities (Todorova and Durisin, 2007).

Consistent with the dynamic capabilities, PAC makes a firm receptive to external knowledge by allowing the firm to identify and assimilate external knowledge that is necessary to improve performance-oriented activities (Fosfuri and Tribó, 2008). Coopetitive relationships are potentially useful grounds for PAC to absorb useful external knowledge since coopetitors tend to possess similar knowledge, infrastructure, and technological capabilities (Gnyawali and Park, 2011, Bouncken and Fredrich, 2016). Additionally, the knowledge scanning abilities of PAC allows coopetitors to quickly acquire necessary knowledge from each other and apply it for various benefits (Ritala and Hurmelinna-Laukkanen, 2013). Such knowledge absorptions could result not only in firms generating new products and technologies, but also enhance the value of existing product lines by utilizing the unique combinations of resources (Ritala and Hurmelinna-Laukkanen, 2013). Thus, PAC can potentially lead to new as well as incremental innovations.

As for the operational performance, the dynamic capabilities view indicates that the ability of firms to recombine and reconfigure organization-wide capabilities could also impact their operational activities (Teece et al., 1997). Firms tend to gain access to a range of external operational practices from their partnerships; the more operational practices that a firm adopts from external sources by utilizing its absorptive capacity, the larger the body of such knowledge that the firm could gain (Jinhui Wu et al., 2012). Access to a larger body of 
knowledge over operational practices could improve the firm's operational capabilities which may eventually benefit its operational performance (Patel et al., 2012, Obayi et al., 2017) such as improved flexibility, responsiveness, and other operational efficiencies. In effect, we argue that the higher the strength of PAC of a coopetitor, the better the coopetitor's chances to enhance operational performance benefits. Accordingly;

$\mathrm{H}_{3}$ : Potential absorptive capacity has a positive effect on both operational and innovation performance benefits.

\subsection{Contingent effects of strategic intent and potential absorptive capacity}

The importance of capabilities for the EO - performance relationship can be explained from the tenets of dynamic capabilities and relational view theories. Though dynamic capabilities are necessary variables for developing competitive advantage, they alone are not sufficient to sustain the competitive advantage. Therefore, it is appropriate to integrate the dynamic capabilities with existing resources to enhance the resource configurations in order to develop long-term competitive advantage (Eisenhardt and Martin, 2000). Zahra and George (2002) and Eisenhardt and Martin (2000) add that dynamic capabilities can reconfigure a firm's resources to develop and sustain the competitive advantage rather than a firm that merely possess such capabilities without utilising them to reconfigure its resources. However, when it comes to interfirm relationships, firms tend to make use of the relationships to learn from each other to best utilize their capabilities for resource configurations (Dyer and Kale, 2007). The relational view theory adds to this notion by stating that firms value creation opportunities grow stronger when both the partners learn from each other utilizing their complementaries and knowledge (Dyer et al., 2018). This view is attributed to the underlying phenomenon that a firm's capabilities are known to better fit with the capabilities of its partner in an interfirm relationship; this, as a result could lead to complementarity between the capabilities and assist firms to create greater value (Dyer et al., 2018). Furthermore, interfirm relationships could not only facilitate resource and capability flows between partners, but also enable the partners to 
leverage on those to create greater joint value (Dyer and Singh, 1998). In other words, firms can develop their own additional value by combining a proportion of the joint value with their own internal capabilities (Gnyawali and Charleton, 2018). Therefore, both the dynamic capabilities view and the relational view emphasize the significance of capabilities in transforming firms' key resources to generate competitive advantage.

Consistent with these theoretical tenets, entrepreneurial firms require specific capabilities to transform their resources. Specifically, although EO is significant, it need not be a sufficient condition to attain as well as sustain long-term success (Engelen et al., 2014). In other words, without capabilities, EO lacks the means to realize its potential performance outcomes. A firm's absorptive capacity can be a useful capability due to its capacity to recognize and assimilate valuable knowledge from the alliance partner and utilize it to reconfigure the firm's existing resources (Dyer and Singh, 1998). Similarly, SI as a capability can offer clarity on the firm's ambitious and competitive plans, and guide the firm's EO to advance the firm's competitive advantage (Covin et al., 2006). Both these capabilities of PAC (Fosfuri and Tribó, 2008) and SI (Mariadoss et al., 2014) have received particular attention in extant research for their ability to reconfigure resource combinations to produce enhanced performance. Therefore, this study considers PAC and SI as the key moderators to extend current research standing on the $\mathrm{EO}$ - performance relationship.

PAC as a capability could provide firms with a new pattern of resource combinations through the integration of internal and external knowledge (Patel et al., 2015, Obayi et al., 2017). Accordingly, when complemented by PAC, EO could better regulate and facilitate its efforts towards combining diverse knowledge and other resources (Patel et al., 2015). Furthermore, as a dynamic capability, absorptive capacity can assist in implementing entrepreneurial activities effectively and efficiently by dealing with firm's resource uncertainties (Lumpkin and Dess, 1996, Engelen et al., 2014). For instance, the proactiveness 
characteristic of EO tends to be nourished by absorptive capacity to increase the variety of possible positive outcomes through better organisation-wide responsiveness (Liao et al., 2003, Patel et al., 2015). Alternatively, absorptive capacity, with its strong and continuous knowledge inflows, nourishes proactiveness and assists the firm to generate consistent incremental and breakthrough improvements (Liao et al., 2003). The risk-taking characteristic of EO is said to be complemented by absorptive capacity's ability to gather domain specific knowledge and technological advancements (Patel et al., 2015). Such technological advancements could lower the perception of losses and increase the controllability and flexibility of operations in relationships (Obayi et al., 2017). Similarly, EO's competitive aggressiveness complemented by the use of its absorptive capacity could drive a firm's efforts to outperform the rivals in the industry. Taken together, the combined effect of EO and PAC is useful in integrating internal and external knowledge and attaining resource recombination to address market expectations and trends. This can transform a firm to respond aggressively to competition and increase investments in functions such as R\&D as part of the firm's entrepreneurial approach (Patel et al., 2015) to improve its product development efforts as well as operational efficiencies. Accordingly;

$\mathrm{H}_{4}$ : Potential absorptive capacity will positively moderate the effect of a firm's entrepreneurial orientation on its operational and innovation performance.

Alternatively, SI as a dynamic capability can also provide firms with a key source of organizational momentum to initiate the reconfiguration as well as recombination of diverse resources (Teece et al., 1997, Eisenhardt and Martin, 2000). As reckoned by the dynamic capabilities view, SI can act as an useful tool for firms to improve their sensing, seizing, and reconfiguring capabilities (O'reilly and Tushman, 2008). A firm with a strong SI tends to search out and muster all possible resources, such as EO, to utilise them in achieving strategic objectives as well as competitive advantage (Johnson and Sohi, 2001, Han et al., 2018). It is attributed to the fact that a firm that has a clear sense of entrepreneurial vision and the SI of 
achieving competitive dominance and strategic goals (Hamel and Prahalad, 1989) could embed that vision so as to formulate an appropriate entrepreneurial strategy (Ireland et al., 2001). Such an entrepreneurial strategy, driven by a combination of EO and SI that can guide organizationwide resources and capabilities towards greater performance attainments, is likely to have a positive impact on the firm's performance over time. On the other hand, without the assistance of relevant complementary capabilities such as the SI that could guide the entrepreneurial activities, EO might lack the means to realise the desired outcomes (Engelen et al., 2014). Therefore, we forward the following hypothesis for formal testing.

$\mathrm{H}_{5}$ : Strategic intent will positively moderate the effect of a firm's entrepreneurial orientation on its operational and innovation performance.

\section{METHODOLOGY}

\subsection{Industry context and data collection}

The variables employed within the study represent firm-specific resource and capabilities that could lead firms to benefit from their relationship with horizontal coopetitor partners. Therefore, given that we explore the performance benefits within a relationship, our unit of analysis is the horizontal coopetition relationship. To test the proposed theoretical model, we have collected data from a cross-sectional sample drawn from a simple random survey of firms from North America including the USA and Canada, and from the north European countries of UK, Ireland, and Netherlands. The selection of these geographical locations is made based on the principles that (1) these locations host high concentration of knowledge-intensive and hightechnology firms which is the intended industrial background for this study, and (2) OECD TL3 database (Organization for Economic Cooperation and Development - Territory Level 3) (Righetto et al., 2019) as well as Eurostat's database (Eurostat, 2018) indicate an increasing trend in collaborations between firms with technology and knowledge-intensive industrial backgrounds in these locations. We selected industries including automotive, electronics, 
engineering, and information and communication technologies (ICT) as these are recognized as knowledge-intensive as well as hi-tech by the Eurostat (Eurostat, 2018). Additionally, extant research also suggests that coopetitive relationships are more prevalent in these sectors (Gnyawali and Park, 2011, Wilhelm and Sydow, 2018); therefore, selection of these sectors appear to be more pragmatic.

A web-based questionnaire was used for collecting survey data. We employed the 'Qualtrics' software tools to develop the web-survey questionnaire. An extensive literature review was carried out to identify the survey questions; the questions and their sources are highlighted in section 3.3. The response to the questionnaires is solicited from managers that held operational and strategic positions and are knowledgeable about the firm and its strategic relationship with a competitor partner. To make sure that the web-survey was completed by key respondents, we used a screening question "Does your firm cooperate and compete at the same time with a competitor firm or a firm that has similar product/service offering and similar target market" (indicating a horizontal coopetitive relationship) right after the survey preamble. For clarity, we included horizontal coopetition examples in the survey preamble (e.g., Sony and Samsung). The respondents that chose 'No' to the screening question are automatically screened out from answering the survey; it is to ensure that the survey's responses represent horizontal coopetition relationships only. We collected the data during the period starting from March/April 2018 until June/July 2018.

Considerable financial resources as well as time was invested to identify the firms that pursue horizontal coopetition relationships within the selected sectoral backgrounds. We have collaborated with 'Qualtrics' to identify suitable firms from their robust panel database utilizing the criteria that we have provided beforehand - this includes deliberating with them about the specific context of our study, sectoral backgrounds, potential firms and respondents characteristics. The use of 'Qualtrics' panel services is increasingly becoming popular in both 
OM studies (Verghese et al., 2019) as well as across research functions (Statsenko and Corral de Zubielqui, 2020). Following these criteria-based firms identification, our final sampling frame consisted of 1500 firms that engage in horizontal coopetition relationships. A combination of the criteria that were strictly adhered during the data collection such as focusing on firms from only the knowledge-intensive and hi-tech sectors, developed western countries, and screening out responses from non-horizontal coopetition relationships, makes our sample frame to be representative of the population. The on-line surveys were sent to the 1500 firms in our sampling frame. After several rounds of reminders, we received 355 responses - a $23.67 \%$ initial response rate. We rejected 42 responses from the original 355 responses due to incomplete information, thereby resulting in an effective response rate of $20.87 \%$. An overview of sample characteristics that include the firm as well as the respondent characteristics is presented in Table 1.

-- Insert Table 1 here --

\subsection{Non-response bias and common method bias}

The study assessed non-response bias by comparing the sample means between important demographic variables - firm age and size. The responses were separated into two groups based on when they were received. First 3 weeks of responses were labelled as group 1 while the later responses were labelled as group 2. Group comparison tests showed no significant differences between these groups, thus providing evidence that non-response bias is not a concern. The survey was answered by a single respondent within each sample firm; therefore, specific tests were performed to rule out any concerns related to common method bias. These involved a confirmatory factor analysis (CFA) approach (Sea-Jin et al., 2010). We ran a single-factor CFA analysis. The model fit for this single-factor model $-\mathrm{CFI}=0.835, \mathrm{IFI}=0.836, \mathrm{TLI}=0.818$, RMSEA $=0.101$, normed $\chi 2[\mathrm{NC}]=4.164-$ was significantly worse than the model fit of our 
measurement model. Generally, this result suggests that a single factor will not account for all the variance in our data.

\subsection{Measurement items}

As indicated earlier, the measurement items used in our study were derived from extant literature. A seven-point Likert scale with "strongly disagree" to "strongly agree" as anchors is utilized to measure all the indicators of independent, moderation, and operational outcomes variables; for the innovation performance variables, "no such benefits" to "very high benefits" are used as anchors. Please refer to the Appendix for the indicators used in our study.

\section{Entrepreneurial orientation}

The independent variable of "EO" with its three dimensions - proactiveness, risk-taking, and strategic aggressiveness - is operationalised on a five items scale and is adapted from Atuahene-Gima and Ko (2001). This operationalization method does not include 'innovativeness' characteristic of EO but instead includes 'strategic aggressiveness'. This style of operationalization is chosen due to an underlying assumption that when innovativeness characteristic is already part of the EO measurement, the chances for firms to attain the innovation performance may become an obvious outcome.

\section{Potential absorptive capacity and strategic intent}

A four items scale from Ritala and Hurmelinna-Laukkanen (2013) was adapted to operationalise "PAC". As for "SI", it was operationalized using a four items scale from Johnson and Sohi (2001); We have included only four items from the eight items scale that was originally utilized by Johnson and Sohi (2001). This is to ensure that our measurement of SI is in line with the context of our study. Similar practice was also adopted in earlier studies such as Mariadoss et al. (2014) that have utilized only three items to measure SI.

\section{Innovation and operational performance outcomes}


Measures for "Operational performance" were adapted from McDermott and Stock (1999) and Zacharia et al. (2011). "Incremental innovation" and "radical innovation" are measured on a three items scale each and are adapted from Ritala and Hurmelinna-Laukkanen (2013), Chandy and Tellis (1998), and Kim et al. (2012). Specifically, the respondents were requested to respond to these innovation-related queries as per the performance benefits they had gained in the past three to five years from the specific horizontal coopetitive relationship chosen.

\section{Control variables}

We included various control variables that could impact our performance measures. We controlled for relationship length because firms could gain incentives from their engagement in relationships which can be later utilised to influence the relationship (Verghese et al., 2019). We controlled for firm size as larger firms likely prevent the exploitation of opportunities to be pursued by relatively smaller partners in relationships ( $\mathrm{Li}$ et al., 2017). We also controlled for Firm age as it is likely to affect the outcomes of a relationship as older firms can use their industry establishment for personal benefits (Anderson and Eshima, 2013). New product development, amount of $R \& D$ collaboration as well as technology development were also controlled for as these items indicate the intensity and strength of alliance activities between the partners in coopetition (Seepana et al., 2020) which likely influence the performance outcomes. Geographical/country location is also controlled for, since location-specific characteristics can influence innovation outcomes in interfirm relationships (Potter and Paulraj, 2020).

\subsection{Assessing instrument development}

The survey instrument was grounded in extant literature so as to ensure the content validity of the measurement items. In addition, as part of our pre-testing process, we solicited opinions on the survey instrument from fifteen industry experts as well as four senior academics; these experts also commented on the completeness as well as overall structure of our survey 
instrument (Dillman, 2007). Following expert opinions, we made minor changes to the survey instrument. We conducted normality and outliers tests to nullify potential outliers. These were determined based on the statistics of skewness and kurtosis as well as the plots of residuals. The maximum absolute values of these tests were within the acceptable limits of 2 and 7 (Curran et al., 1996). Additionally, the resultant plots did not indicate significant deviations.

The results for construct validity and unidimensionality are included in the Appendix. In the case of exploratory factor analysis, the items loaded dominantly onto their respective constructs. The model fit indices of the confirmatory factor analysis also indicate adequate fit: $\mathrm{CFI}=0.946, \mathrm{IFI}=0.947, \mathrm{TLI}=0.936, \mathrm{SRMR}=0.0397$, normed $\chi^{2}[\mathrm{NC}]=2.111$, and $\mathrm{RMSEA}$ $=0.060($ Kline, 2005). Overall, the results assert that our proposed measurement items were valid and reliable. The results also established discriminant validity based on the Fornell and Larcker test (Fornell and Larcker, 1981). All constructs were found to meet the discriminant validity test except between EO and incremental innovation and incremental and radical innovations. The squared correlation of incremental innovation is slightly higher than that of EO. Eliminating one item from EO measures (Strong emphasis on research and development, technological leadership, and innovation) would resolve the correlation issue. However, we retained the measure to give due consideration to the significance of $\mathrm{R} \& \mathrm{D}$, technology, and innovation for EO to generate performance outcomes. The relatively high correlation between outcome variables of incremental and radical innovation is widely prevalent in extant literature (McDermott and Prajogo, 2012, Forés and Camisón, 2016); this phenomena is linked to the close nature of constructs such as types of innovations (Chang et al., 2014) or knowledgerelated variables (Jiménez-Jiménez and Sanz-Valle, 2011). The AVE values are presented in the Appendix while the correlation values are displayed in Table 2. Furthermore, to assess potential multi-collinearity issues, variance inflation factor (VIF) values were computed - the values were found to be below 5 (highest VIF = 2.204) (Hair et al., 2012). 
Reliability was checked using multiple measures. Initially, we evaluated the coefficient alpha (Nunnally, 1978) and coefficient omega (McDonald, 1999) values. Though coefficient alpha is an important measure to assess reliability, scholars suggest that it does not yield a consistent estimate of reliability when the underlying items are not tau-equivalent (Deng and Chan, 2017). Although all our model's constructs had a coefficient alpha value higher than 0.70, the items within SI, radical innovation and operational outcomes were not tau-equivalent. Therefore, we have reported both coefficient alpha and coefficient omega in the Appendix. Additionally, all the constructs have composite reliability (CR) values higher than 0.70 (Hair et al., 2012). Furthermore, all constructs also have AVE values higher than 0.50. In effect, our results suggest that the indicators utilised in the model are valid, unidimensional, as well as reliable. Some indicators were excluded (please refer to the Appendix) in the process of the instrument development due to them not meeting the established psychometric requirements.

$$
\text { -- Insert Table } 2 \text { here -- }
$$

\section{ANALYSIS AND FINDINGS}

Table 3 presents the results pertaining to hypotheses $\mathrm{H} 1$ through $\mathrm{H} 5$. Hypothesis $\mathrm{H} 1$ suggests EO to have a positive effect on operational and innovation performance. Results show that EO's effect on operational performance (Model 1) $(\beta=0.293, \mathrm{p}<0.0001)$, incremental innovation (Model 3) $(\beta=0.378, \mathrm{p}<0.0001)$, and radical innovation (Model 5) $(\beta=0.410, \mathrm{p}$

$<0.0001)$ are positive and significant, thereby supporting hypothesis H1. As for the performance effect of SI, results suggest that SI's effect on operational performance (Model 1) $(\beta=0.191, \mathrm{p}<0.0001)$, incremental innovation (Model 3) $(\beta=0.084, \mathrm{p}<0.05)$, and radical innovation (Model 5) $(\beta=0.111, \mathrm{p}<0.05)$ are positive and significant. Additionally, results also indicate that PAC's effect on operational performance (Model 1) $(\beta=0.379, \mathrm{p}<0.0001)$, incremental innovation (Model 3) $(\beta=0.384, \mathrm{p}<0.0001)$, and radical innovation (Model 5) $(\beta$ 
$=0.257, \mathrm{p}<0.0001)$ are positive and significant. Thus, these results offer support for hypotheses $\mathrm{H} 2$ and $\mathrm{H} 3$.

Hypotheses H4 and H5 focused on the moderating effect of 'PAC' and 'SI'. Results show that the moderation effect of SI on the relationship between EO and operational performance $(\beta=-0.136, \mathrm{p}<0.01)$ is negative and significant, whereas the moderation effect of $\mathrm{PAC}$ on the relationship between $\mathrm{EO}$ and operational performance $(\beta=0.097, \mathrm{p}>0.05)$ is positive, but insignificant (Model 2). Further, results show that SI's moderation effect on the relationship between EO and incremental relationship $(\beta=-0.133, \mathrm{p}<0.01)$ is negative and significant, whereas PAC's moderation effect on the relationship between EO and incremental innovation 'PAC and EO' $(\beta=0.087, \mathrm{p}>0.05)$ is positive, but insignificant (Model 4). When it comes to radical innovation, results show that SI's moderation effect between EO and radical innovation $(\beta=-0.100, \mathrm{p}>0.05)$ is negative and insignificant while PAC's moderation effect on the relationship between EO and radical innovation $(\beta=0.093, \mathrm{p}>0.05)$ is positive and insignificant (Model 6). These results do not find support for hypotheses H4 and H5. Figure 1 displays the conceptual model with summarised results.

-- Insert Figure 1 here --

We also tested the moderation effects using the SPSS macro PROCESS designed by Hayes (2018). The bias-corrected confidence intervals (Preacher et al., 2006) for all the moderation effects were in line with our above results: moderation effect of SI $(95 \% \mathrm{CI}=-$ 0.154 to -0.022$)$ and $\mathrm{PAC}(95 \% \mathrm{CI}=-0.009$ to $0.139 ; n s)$ on the path between $\mathrm{EO}$ and operational performance; moderation effect of SI (95\% CI $=-0.155$ to -0.030$)$ and PAC (95\% $\mathrm{CI}=-0.008$ to $0.132 ; n s)$ on the path between $\mathrm{EO}$ and incremental innovation; moderation effect of SI $(95 \% \mathrm{CI}=-0.144$ to $0.002 ; n s)$ and PAC $(95 \% \mathrm{CI}=-0.014$ to $0.148 ; n s)$ on the path between EO and radical innovation. 


\section{DISCUSSION}

The study makes numerous contributions to both the theory as well as practice within the context of coopetitive relationships. The study's first objective is to examine the effects of a firm's EO, SI, and PAC on the firm's innovation as well as operational performance, specifically in the context of a horizontal coopetitive relationship. As for the EO's effects on innovation, our result is consistent with the views of strategic alliance studies such as Jiang et al. (2016) that suggest that a firm's EO could positively impact the innovation performance. However, our findings add to extant literature by examining EO's effects on both radical and incremental innovations; we find that EO could have a positive effect on both types of innovation. Further, our findings also suggest that EO could positively impact operational performance. This finding contradicts previous studies that suggest the non-existence of a direct effect between EO and operational outcomes (Walter et al., 2006). However, Walter's study was carried out in a non-coopetition context.

EO's performance effects may also have certain influence from its operationalization. Given that EO has been operationalized differently in our study, it compels to adequately comprehend whether EO impacts the performance outcomes differently for different operationalizations of the EO. Previous studies including Jiang et al. (2016), Bouncken et al. (2016), and Li et al. (2011) determine EO as an aggregate measure of innovativeness, risktaking, and proactiveness where innovativeness of EO could potentially influence innovation generation abilities of a given firm. However, the aggregate measure of EO in this study includes strategic aggressiveness (in place of innovativeness), proactiveness, and risk-taking following Atuahene-Gima and Ko (2001). The strategic or competitive aggressiveness plays a significant part in increasing both the volume and diversity of competitive activities undertaken by a coopetitor to accomplish superior performance (Sanou et al., 2016). The underlying rationale is that aggressiveness assists firms to exploit resources more swiftly (Clark and 
Montgomery, 1998, Morgan and Strong, 2003); thus, it increases the firm's potential to produce better performance benefits such as product/process innovation and business efficiencies (Zahra, 1993). Therefore, our operationalization clarifies an underlying argument that EO is capable of delivering better performance in coopetitive relationships irrespective of whether the innovativeness characteristic is part of the EO measurement. In essence, our results are in line with extant research which posits that EO, as an overarching construct (combination of all of its characteristics rather than one in particular), is capable of delivering positive performance benefits using the joint strength of the combinations of its characteristics (Wiklund and Shepherd, 2005, Handfield et al., 2009).

Regarding SI's effects on innovation and operational performance, the results add to previous literature that posit SI to be capable of delivering performance benefits (Mariadoss et al., 2014, Contiero et al., 2016). Within coopetition context, our results explicitly indicate that SI, as an important capability of a coopetitor, can lead to both innovation and operational performance. The SI of attaining strategic goals and competitive dominance necessitate a firm to emphasize on exploring opportunities for improvement and exploiting the available skills and capabilities (Koza and Lewin, 2000, Seepana et al., 2020). When it comes to coopetition, as reckoned by the relational and dynamic capabilities views (Dyer et al., 2018) as well as extant literature (Gnyawali and Charleton, 2018, Seepana et al., 2020), it offers greater access to coopetitors so that they learn from each other's experiences (Bouncken and Fredrich, 2016). This learning could benefit coopetitors in exploring opportunities for innovations and performance improvements. It could guide them to combine their learning, resources and skills to attain key performance benefits (innovation and operational performance in our case) that can offer competitive advantage and leadership positions.

As for PAC's performance effects, studies such as Ritala and Hurmelinna-Laukkanen (2013) indicate that PAC can lead to innovations in coopetitive relationships; our findings 
further reinforce these studies. However, for radical innovation, potential absorptive capacity was conjectured to have an insignificant effect (Ritala and Hurmelinna-Laukkanen, 2013). On the contrary, our findings indicate a significant positive association between PAC and radical innovation. Our study also expands the scope of PAC's performance impacts to operational outcomes. This is an interesting finding given that only few studies have tested absorptive capacity-operational performance relationship within interfirm relationships context (Ex Whitehead et al., 2016, Sáenz et al., 2014), and some studies including that of Whitehead et al. (2016) found no direct relationship. But our result reinforces PAC's ability to assimilate and transform operational knowledge from external sources, specifically from the coopetitive partner, and integrate such knowledge across its internal functions to improve operational efficiencies (Patel et al., 2012, Jinhui Wu et al., 2012).

The study's second objective is to investigate how SI and PAC could moderate the relationships between EO and performance outcomes. Both SI and PAC did not appear to positively influence EO's effect on the performance. This result alludes to extant research which cautions that 'too much of a good thing', whether it is a combination of resource and capabilities or product/process features, may not necessarily do good for firms (Busse et al., 2016, Thompson et al., 2018). Contrarily, such combinations of capabilities may cause 'feature fatigue' (Thompson et al., 2018), or 'capability fatigue' in our case, which could overwhelm a firm and therefore make it difficult for the firm to benefit by utilizing such combinations. Alternatively, this phenomenon appears to reflect the tenets of Icarus paradox (Miller, 1990). Icarus paradox suggests that certain features which brought success to firms have failed the same firms when they tried to interplay all features at once in an attempt to enhance their success. Our findings clearly point to these phenomena.

SI has a significant negative moderating effect on the EO-performance relationship with the exception being that SI's effect on EO-Radical innovation is insignificant. The findings of 
SI's moderating effects are important as these findings contradict extant literature that suggest that SI is vital for firms to guide their resource allocations and resource based decisions in order to enhance performance (Mariadoss et al., 2014). In other words, SI is supposed to nurture EO to produce better performance outcomes (Covin et al., 2006, McAdam et al., 2014). However, the results suggest the opposite. A potential reason could be that although the combination of core competency (EO in this case) and SI are necessary requirements to attain success (Kickul et al., 2011), it can become an optimally-aligned combination of resource and capability that can only serve the purpose of a firm's current/today's operations rather than the long-term sustained performance into the future (Hamilton et al., 1998). It is better for a firm to have an optimally-misaligned resource and capability combination (rather than aggressive strategic resources and capabilities combinations) in pursuit of strategic goals. This allows the firm to test various current resource combinations to attain incremental goals and receive performance feedback on them and thereby utilize a better combination of resource and capability to attain strategic goals (Hamilton et al., 1998) involving innovations that could sustain the business. For instance, EO necessitates continuous R\&D investments which will become a burden for firms to sustain over time. Therefore, the firms might have to make alternative complementary resource arrangements to complement the strategic intent to attain strategic goals (Mariadoss et al., 2014). Consequently, a combination of a firm's EO and SI will not necessarily benefit the firm's performance.

In the case of PAC, its moderation effect on the relationship between EO and performance is insignificant. This result did not align with previous research that suggests a complementary association between PAC and EO to deliver enhanced operational outcomes (Patel et al., 2015). However, this study was conducted in non-coopetition context. The insights from our study indicate that a strong PAC delivers neither EO-operational performance nor EO-innovation performance. These findings suggest that although coopetitors boast of 
possessing multiple competitive capabilities, such capabilities may not necessarily aid in transforming the key resources into higher performance benefits.

This enriching phenomena of negative moderating effects can be further attributed to the possible intense competition caused by the competitive capabilities of SI and PAC. Firms' use of competitive capabilities seek rapid advancements and potentially instigate competitive expectations due to learning races and internalization of partners' resources (Cao and Zhang, 2011). This will reflect in competitive intensities which cause hostilities within the operating environment (Zahra and Covin, 1995), thereby causing friction between the coopetitive partners. Referring to the competitive intensities, Sahi et al. (2019) suggested that EOperformance association will only become fruitful when the intensity of competition caused by different variables, such as interactive competitive capabilities, is not high. Besides, coopetition being an already competitive relationship (Gnyawali and Charleton, 2018) could further heighten the competitive intensities when coopetitors utilize competitive capabilities to seek higher firm-level benefits from the relationship. Such an intense competition might motivate a tug of war among firms, thereby consuming excessive resources so as to beat the competition.

These situations leave entrepreneurial firms with few critical resources to innovate, thus negating their abilities to be aggressive and take risks (Sahi et al., 2019). Therefore, we forward that a coopetitor's use of competitive capabilities of PAC and SI to complement EO in an effort to enhance the firm's performance benefits could possibly intensify the competition with its partner, and eventually reduce the firm's likelihood to benefit from its EO. This finding further adds to OM research that seeks to explore how entrepreneurially oriented firms leverage their resource and capability combinations (Kickul et al., 2011, Sahi et al., 2019). In effect, we believe that this result signifies the presence of the Icarus paradox (Miller, 1990), wherein too much of a good thing might actually hurt firms (Busse et al., 2016), particularly in competitive relationships. Furthermore, this result also adds to studies that seek to investigate performance 
effects of the complementarity between coopetitors' strategic resources and capabilities (Bouncken and Fredrich, 2016, Hoffmann et al., 2018).

To shed better light on this paradox, we present the confidence bands for the moderating effects of PAC and SI using the bootstrapping approach (Preacher et al., 2006); the results were based on 5000 replications. The confidence bands included in Figure 2 exhibit how SI and PAC moderate the EO-performance relationship. The confidence bands drawn based on the results suggest that EO has significant conditional indirect effect on performance outcomes at most levels of PAC and SI. At the same time, the results appear to suggest that EO's effect on the performance outcomes is getting minimized at higher levels of both PAC and SI. On the contrary, the EO's effect on performance outcomes is higher when PAC and SI is kept low. This essentially explains that firms' use of competitive capabilities to transform their strategic resources such as EO to produce better outcomes is not particularly fruitful in coopetition. Therefore, firms in such relationships need to be watchful when it comes to the utilization of a combination of capabilities to reconfigure their key resources or utilize individual strategic resources or capabilities to target higher benefits from the relationship. As far as the study is concerned, lowering the use of competitive capabilities of SI and PAC might help firms to gain better benefits from their entrepreneurial orientation.

-- Insert Figure 2 here --

\section{Managerial Implications}

Our study offers numerous implications for managers involved in horizontal coopetitive relationships. Specifically, our results motivate managers to focus on prioritization and effective utilisation of their firm-level intangible, yet competitive, resources and capabilities to gain better performance benefits for their firms. Pursuing high levels of EO with strong emphasis on aggressive technology investments and R\&D activities would likely improve their chances of reaping better benefits in strategic relationships. Besides, managers are likely to 
benefit from the use of firm-level capabilities such as SI and PAC independently, considering their ability to consistently focus on achieving ambitious goals and acquiring necessary new resources and information. However, the use of both of these capabilities to complement their firm's strategic resources such as EO to gain better benefits may not be plausible in coopetitive relationships given that the use of competitive capabilities along with their EO might signal the firm to be too hostile to their partner firms. This could potentially dilute the partner's motivation to continue to engage in the relationship and eventually affect the firm's chances to gain potential performance benefits.

\section{CONCLUSION, LIMITATIONS, AND FUTURE RESEARCH DIRECTION}

The question about the potential benefits that EO as a resource, and SI and PAC as capabilities can bring to firms has been receiving increased attention in operations as well as strategic management literature (Kickul et al., 2011, McAdam et al., 2014, Patel et al., 2015). Given their underlying significance, it is becoming increasingly important for organisations, academics, and practitioners to understand not only performance effects, but also the underlying complementary interactions of EO, SI, and PAC. It is important to test these relationships not only due to the lack of evidence, but also because literature emphasizes them to be an important and integral part of firms involved in coopetitive relationships (Luo, 2007, Li et al., 2011, Seepana et al., 2020). Further, our study provides nuanced arguments for the complementarity between internal resources and competitive capabilities in the case of firms involved in competitive relationships. Overall, our study contributes to extant research by empirically showing that while EO, SI, and PAC could deliver performance benefits on their own, their interaction effects might not be beneficial.

As is the case with most research, our study is also not without its limitations. This study is developed by collecting data from one firm of each horizontal coopetition relationship which represents one side of each dyad. This could partly affect the interpretations of a study's 
findings (Cao and Zhang, 2011). However, this phenomenon is a frequent occurrence in research studying strategic relationships (Robson et al., 2019); and that explaining the relational effects from a single firm perspective of a strategic alliance is generally plausible (Jiang et al., 2016). Our cross-sectional survey design means that causality likely could not be established empirically. Therefore, future studies may verify these relationships using a longitudinal research design (Li et al., 2011). Although this study investigates EO as a resource and SI and PAC as key capabilities of coopetitors, there may be other resources such as 'strategic orientation' and 'technology orientation' that can substitute EO as a resource that the coopetitors could possess but these are not addressed in this study. Therefore, future studies may find research in this direction to be interesting. There may be other mechanisms that could potentially affect the way that EO could impact performance outcomes. These may include, but not limited to, relational variables (idiosyncratic resources, knowledge sharing, complementary etc.,) as well as industry level variables (technology conditions, market conditions, institutional environment etc). Future studies may investigate moderation effects of these variables on the EO-performance relationship. There could be various models/configurations of coopetition such as cooperation-dominated coopetition, competitiondominated coopetition, strong-coopetition, and weak-coopetition (Bengtsson et al., 2016); performance effects of these models likely vary with respect to different sectoral backgrounds which this study could not investigate. Future studies might find research in this direction to be intriguing.

\section{REFERENCES}

ANDERSON, B. S. \& ESHIMA, Y. 2013. The influence of firm age and intangible resources on the relationship between entrepreneurial orientation and firm growth among Japanese SMEs. Journal of Business Venturing, 28, 413-429.

ATUAHENE-GIMA, K. \& KO, A. 2001. An Empirical Investigation of the Effect of Market Orientation and Entrepreneurship Orientation Alignment on Product Innovation. Organization Science, 12, 54 74. 
BARNEY, J. 1991. Firm Resources and Sustained Competitive Advantage. Journal of Management, 17, 99-120.

BENGTSSON, M., RAZA-ULLAH, T. \& VANYUSHYN, V. 2016. The coopetition paradox and tension: The moderating role of coopetition capability. Industrial Marketing Management, 53, 19-30.

BOUNCKEN, R., PLÜSCHKE, B., PESCH, R. \& KRAUS, S. 2016. Entrepreneurial orientation in vertical alliances: joint product innovation and learning from allies. Review of Managerial Science, 10, 381-409.

BOUNCKEN, R. B. \& FREDRICH, V. 2016. Learning in coopetition: Alliance orientation, network size, and firm types. Journal of Business Research, 69, 1753-1758.

BUSSE, C., MAHLENDORF, M. D. \& BODE, C. 2016. The ABC for Studying the Too-Much-of-a-GoodThing Effect: A Competitive Mediation Framework Linking Antecedents, Benefits, and Costs. Organizational research methods, 19, 131-153.

CAO, M. \& ZHANG, Q. 2011. Supply chain collaboration: Impact on collaborative advantage and firm performance. Journal of Operations Management, 29, 163-180.

CEPEDA-CARRION, G., CEGARRA-NAVARRO, J. G. \& JIMENEZ-JIMENEZ, D. 2012. The Effect of Absorptive Capacity on Innovativeness: Context and Information Systems Capability as Catalysts. British Journal of Management, 23, 110-129.

CHANDY, R. \& TELLIS, G. 1998. Organizing for Radical Product Innovation: The Overlooked Role of Willingness to Cannibalize. Journal of Marketing Research, 35, 474.

CHANG, W., FRANKE, G. R., BUTLER, T. D., MUSGROVE, C. F. \& ELLINGER, A. E. 2014. Differential Mediating Effects of Radical and Incremental Innovation on Market Orientation-Performance Relationship: A Meta-Analysis. Journal of Marketing Theory and Practice, 22, 235-250.

CHANG, Y., WANG, X. \& CUI, A. P. 2019. Solving the innovation problem in state-owned firms: The role of entrepreneurial orientation and high-commitment HR practices. Industrial marketing management, 83, 239-250.

CLARK, B. H. \& MONTGOMERY, D. B. 1998. Competitive reputations, multimarket competition and entry deterrence. Journal of Strategic Marketing, 6, 81-96.

CONTIERO, E., PONSIGNON, F., SMART, P. \& VINELLI, A. 2016. Contingencies and characteristics of service recovery system design: Insights from retail banking. International Journal of Operations \& Production Management, 36, 1644-1667.

COVIN, J. G., GREEN, K. M. \& SLEVIN, D. P. 2006. Strategic Process Effects on the Entrepreneurial Orientation-Sales Growth Rate Relationship. Entrepreneurship Theory and Practice, 30, 5781.

COVIN, J. G. \& LUMPKIN, G. T. 2011. Entrepreneurial Orientation Theory and Research: Reflections on a Needed Construct. Entrepreneurship theory and practice, 35, 855-872.

CURRAN, P., WEST, S. \& FINCH, J. 1996. The Robustness of Test Statistics to Nonnormality and Specification Error in Confirmatory Factor Analysis. Psychological Methods [PsycARTICLES], 1, 16.

DENG, L. \& CHAN, W. 2017. Testing the Difference Between Reliability Coefficients Alpha and Omega. Educational and Psychological Measurement, 77, 185-203.

DENG, P. 2004. Outward investment by Chinese MNCs: Motivations and implications. Business Horizons, 47, 8-16.

DILLMAN, D. A. 2007. Mail and internet surveys : the tailored design method, Hoboken, N.J., Wiley.

DYER, J. \& KALE, P. 2007. Relational Capabilities: Drivers and Implications. In: HELFAT, C. E., FINKELSTEIN, S., MITCHELL, W., PETERAF, M. A., SINGH, H., TEECE, D. J. \& WINTER, S. G. (eds.) Dynamic Capabilities: Understanding Strategic Change In Organizations. Oxford: Blackwell Publishing.

DYER, J. \& SINGH, H. 1998. The relational view: cooperative strategy and sources of interorganizational competitive advantage. Academy of Management review, 23, 660-679.

DYER, J. H., SINGH, H. \& HESTERLY, W. S. 2018. The relational view revisited: A dynamic perspective on value creation and value capture. Strategic management journal, 39, 3140-3162. 
EISENHARDT, K. \& MARTIN, J. 2000. Dynamic capabilities: what are they? Strategic management journal, 21, 1105-1122.

ENGELEN, A., KUBE, H., SCHMIDT, S. \& FLATTEN, T. C. 2014. Entrepreneurial orientation in turbulent environments: The moderating role of absorptive capacity. Research Policy, 43, 1353-1369.

EUROSTAT 2018. Eurostat statistics explained, Glossary: High-tech (High-tech aggregation by NACE Rev.2).

FORÉS, B. \& CAMISÓN, C. 2016. Does incremental and radical innovation performance depend on different types of knowledge accumulation capabilities and organizational size? Journal of Business Research, 69, 831-848.

FORNELL, C. \& LARCKER, D. 1981. Evaluating structural equation models with unobservable variables and measurement error. Journal of marketing Research, 18, 39-50.

FOSFURI, A. \& TRIBÓ, J. A. 2008. Exploring the antecedents of potential absorptive capacity and its impact on innovation performance. Omega, 36, 173-187.

GNYAWALI, D. \& PARK, B.-J. 2011. Co-opetition between giants: Collaboration with competitors for technological innovation. Research Policy, 40, 650-663.

GNYAWALI, D. R. \& CHARLETON, T. R. 2018. Nuances in the Interplay of Competition and Cooperation: Towards a Theory of Coopetition. Journal of Management, 44, 2511-2534.

HAIR, J. F., SARSTEDT, M., RINGLE, C. M. \& MENA, J. A. 2012. An assessment of the use of partial least squares structural equation modeling in marketing research. Journal of the Academy of Marketing Science, 40, 414-433.

HAMEL, G., DOZ, Y. \& PRAHALAD, C. 1989. Collaborate with Your Competitors -- and Win. Harvard Business Review, 67, 133.

HAMEL, G. \& PRAHALAD, C. 1989. Strategic Intent. Harvard Business Review, 67, 63-76.

HAMILTON, R. D., III, ESKIN, E. D. \& MICHAELS, M. P. 1998. Assessing Competitors: the Gap between Strategic Intent and Core Capability. Long range planning, 31, 406-417.

HAN, W., HUANG, Y. \& MACBETH, D. 2018. Performance measurement of cross-culture supply chain partnership: a case study in the Chinese automotive industry. International Journal of Production Research, 56, 2437-2451.

HANDFIELD, R., PETERSEN, K., COUSINS, P. \& LAWSON, B. 2009. An organizational entrepreneurship model of supply management integration and performance outcomes. International Journal of Operations \& Production Management, 29, 100-126.

HAYES, A. F. 2018. Introduction to Mediation, Moderation, and Conditional Process Analysis : a Regression-Based Approach, New York, NY, The Guilford Press.

HELFAT, C. E., FINKELSTEIN, S., MITCHELL, W., PETERAF, M. A., SINGH, H., TEECE, D. J., WINTER, S. G. \& MARITAN, C. A. 2007. Dynamic Capabilities and Organizational Processes. Dynamic Capabilities: Understanding Strategic Change In Organizations. Oxford: Blackwell Publishing.

HITT, M. 2011. RELEVANCE OF STRATEGIC MANAGEMENT THEORY AND RESEARCH FOR SUPPLY CHAIN MANAGEMENT. Journal of Supply Chain Management, 47, 9-13.

HITT, M., TYLER, B., HARDEE, C. \& PARK, D. 1995. Understanding strategic intent in the global marketplace. The Academy of Management Executive, 9, 12.

HOFFMANN, W., LAVIE, D., REUER, J. J. \& SHIPILOV, A. 2018. The interplay of competition and cooperation. Strategic Management Journal, 39, 3033-3052.

IRELAND, R., HITT, M., CAMP, S. \& SEXTON, D. 2001. Integrating entrepreneurship and strategic management actions to create firm wealth. The Academy of Management Executive, 15, 4963.

JIANG, X., YANG, Y., PEI, Y.-L. \& WANG, G. 2016. Entrepreneurial Orientation, Strategic Alliances, and Firm Performance: Inside the Black Box. Long Range Planning, 49, 103-116.

JIMÉNEZ-JIMÉNEZ, D. \& SANZ-VALLE, R. 2011. Innovation, organizational learning, and performance. Journal of Business Research, 64, 408-417. 
JINHUI WU, S., MELNYK, S. A. \& SWINK, M. 2012. An empirical investigation of the combinatorial nature of operational practices and operational capabilities. International Journal of Operations \& Production Management, 32, 121-155.

JOHNSON, J. L. \& SOHI, R. S. 2001. The influence of firm predispositions on interfirm relationship formation in business markets. International Journal of Research in Marketing, 18, 299-318.

KICKUL, J. R., GRIFFITHS, M. D., JAYARAM, J. \& WAGNER, S. M. 2011. Operations management, entrepreneurship, and value creation: Emerging opportunities in a cross-disciplinary context. Journal of Operations Management, 29, 78-85.

KIM, D.-Y., KUMAR, V. \& KUMAR, U. 2012. Relationship between quality management practices and innovation. Journal of Operations Management, 30, 295-315.

KLINE, R. B. 2005. Principles and practice of structural equation modeling, New York, Guilford.

KOZA, M. \& LEWIN, A. 2000. Managing partnerships and strategic alliances: raising the odds of success. European Management Journal, 18, 146-151.

LAWSON, B. \& POTTER, A. 2012. Determinants of knowledge transfer in inter-firm new product development projects. International Journal of Operations \& Production Management, 32, 1228-1247.

LEE, J. \& SLATER, J. 2007. Dynamic capabilities, entrepreneurial rent-seeking and the investment development path: The case of Samsung. Journal of International Management, 13, 241-257.

LI, L., JIANG, F., PEI, Y. \& JIANG, N. 2017. Entrepreneurial orientation and strategic alliance success: The contingency role of relational factors. Journal of Business Research, 72, 46-56.

LI, Y., LIU, Y. \& LIU, H. 2011. Co-opetition, distributor's entrepreneurial orientation and manufacturer's knowledge acquisition: Evidence from China. Journal of Operations Management, 29, 128142.

LIAO, J., WELSCH, H. \& STOICA, M. 2003. Organizational Absorptive Capacity and Responsiveness: An Empirical Investigation of Growth-Oriented SMEs. Entrepreneurship Theory and Practice, 28, 63-86.

LUMPKIN, G. \& DESS, G. 1996. Clarifying the entrepreneurial orientation construct and linking it to performance. Academy of Management. The Academy of Management Review, 21, 135.

LUO, Y. 2007. A coopetition perspective of global competition. Journal of World Business, 42, 129-144.

MANTERE, S. \& SILLINCE, J. A. A. 2007. Strategic intent as a rhetorical device. Scandinavian Journal of Management, 23, 406-423.

MARIADOSS, B. J., JOHNSON, J. L. \& MARTIN, K. D. 2014. Strategic intent and performance: The role of resource allocation decisions. Journal of Business Research, 67, 2393-2402.

MCADAM, R., HAZLETT, S.-A. \& GALBRAITH, B. 2014. The role of performance measurement models in multi level alignment. International Journal of Operations \& Production Management, 34, 1153-1183.

MCDERMOTT, C. M. \& PRAJOGO, D. I. 2012. Service innovation and performance in SMEs. International Journal of Operations \& Production Management, 32, 216-237.

MCDERMOTT, C. M. \& STOCK, G. N. 1999. Organizational culture and advanced manufacturing technology implementation. Journal of Operations Management, 17, 521-533.

MCDONALD, R. P. 1999. Test Theory: A Unified Treatment, Mahwah, NJ, Lawrence Erlbaum.

MILLER, D. 1990. The Icarus Paradox: How Exceptional Companies Bring About Their Own Downfall, New York, Harper Collins.

MITREGA, M., FORKMANN, S., ZAEFARIAN, G. \& HENNEBERG, S. C. 2017. Networking capability in supplier relationships and its impact on product innovation and firm performance. International journal of operations \& production management, 37, 577-606.

MORGAN, R. E. \& STRONG, C. A. 2003. Business performance and dimensions of strategic orientation. Journal of Business Research.

NUNNALLY, J. C. 1978. Psychometric Theory, New York, McGraw-Hill.

O'REILLY, C. A. \& TUSHMAN, M. L. 2008. Ambidexterity as a dynamic capability: Resolving the innovator's dilemma. Research in Organizational Behavior, 28, 185-206. 
OBAYI, R., KOH, S. C., OGLETHORPE, D. \& EBRAHIMI, S. M. 2017. Improving retail supply flexibility using buyer-supplier relational capabilities. International Journal of Operations \& Production Management, 37, 343-362.

PAEK, B. \& LEE, H. 2018. Strategic entrepreneurship and competitive advantage of established firms: evidence from the digital TV industry. International Entrepreneurship and Management Journal, 14, 883-925.

PATEL, P. C., KOHTAMÄKI, M., PARIDA, V. \& WINCENT, J. 2015. Entrepreneurial orientation-asexperimentation and firm performance: The enabling role of absorptive capacity. Strategic Management Journal, 36, 1739-1749.

PATEL, P. C., TERJESEN, S. \& LI, D. 2012. Enhancing effects of manufacturing flexibility through operational absorptive capacity and operational ambidexterity. Journal of Operations Management, 30, 201-220.

POTTER, A. \& PAULRAJ, A. 2020. Building supplier innovation triads: The effects of leadership relationships and alliance partner diversity.

PREACHER, K. J., CURRAN, P. J. \& BAUER, D. J. 2006. Computational Tools for Probing Interactions in Multiple Linear Regression, Multilevel Modeling, and Latent Curve Analysis. Journal of Educational and Behavioral Statistics, 31, 437-448.

RADDATS, C., ZOLKIEWSKI, J., STORY, V. M., BURTON, J., BAINES, T. \& ZIAEE BIGDELI, A. 2017. Interactively developed capabilities: evidence from dyadic servitization relationships. International Journal of Operations \& Production Management, 37, 382-400.

RIGHETTO, L., SPELTA, A., RABOSIO, E. \& PAMMOLLI, F. 2019. Long-term correlations in short, nonstationary time series: An application to international R\&D collaborations. Journal of Informetrics, 13, 583-592.

RITALA, P. \& HURMELINNA-LAUKKANEN, P. 2009. What's in it for me? Creating and appropriating value in innovation-related coopetition. Technovation, 29, 819-828.

RITALA, P. \& HURMELINNA-LAUKKANEN, P. 2013. Incremental and Radical Innovation in CoopetitionThe Role of Absorptive Capacity and Appropriability. Journal of Product Innovation Management, 30, 154-169.

ROBSON, M. J., KATSIKEAS, C. S., SCHLEGELMILCH, B. B. \& PRAMBÖCK, B. 2019. Alliance capabilities, interpartner attributes, and performance outcomes in international strategic alliances. Journal of World Business, 54, 137-153.

RUI, H. \& YIP, G. S. 2008. Foreign acquisitions by Chinese firms: A strategic intent perspective. Journal of World Business, 43, 213-226.

SÁENZ, M. J., REVILLA, E. \& KNOPPEN, D. 2014. Absorptive Capacity in Buyer-supplier Relationships: Empirical Evidence of Its Mediating Role. Journal of Supply Chain Management, 50, 18-40.

SAHI, G. K., GUPTA, M. C., CHENG, T. C. E. \& LONIAL, S. C. 2019. Relating entrepreneurial orientation with operational responsiveness. International Journal of Operations \& Production Management, 39, 739-766.

SANOU, F. H., LE ROY, F. \& GNYAWALI, D. R. 2016. How Does Centrality in Coopetition Networks Matter? An Empirical Investigation in the Mobile Telephone Industry. British Journal of Management, 27, 143-160.

SEA-JIN, C., ARJEN VAN, W. \& LORRAINE, E. 2010. From the Editors: Common method variance in international business research. Journal of International Business Studies, 41, 178.

SEEPANA, C., PAULRAJ, A. \& HUQ, F. A. 2020. The architecture of coopetition: Strategic intent, ambidextrous managers, and knowledge sharing. Industrial marketing management, 91, 100113.

SHIN, H., LEE, J.-N., KIM, D. \& RHIM, H. 2015. Strategic agility of Korean small and medium enterprises and its influence on operational and firm performance. International Journal of Production Economics, 168, 181-196.

STATSENKO, L. \& CORRAL DE ZUBIELQUI, G. 2020. Customer collaboration, service firms' diversification and innovation performance. Industrial Marketing Management, 85, 180-196. 
TEECE, D., PISANO, G. \& SHUEN, A. 1997. Dynamic capabilities and strategic management. Strategic Management Journal, 18, 509-533.

TENG, B. S. 2007. Corporate Entrepreneurship Activities through Strategic Alliances: A Resource-Based Approach toward Competitive Advantage*. Journal of Management Studies, 44, 119-142.

THOMPSON, D. V., HAMILTON, R. W. \& RUST, R. T. 2018. Feature Fatigue: When Product Capabilities Become Too Much of a Good Thing. Journal of marketing research, 42, 431-442.

TODOROVA, G. \& DURISIN, B. 2007. Absorptive capacity: valuing a reconceptualization. Academy of Management review, 32, 774-787.

VERGHESE, A. J., KOUFTEROS, X. \& PETERS, R. 2019. Exploring the dual nature of supplier relationship commitment on buyer behaviors: Considering the levels of buyer-leverage. International journal of operations \& production management, 40, 196-220.

WALES, W., MONSEN, E. \& MCKELVIE, A. 2011. The Organizational Pervasiveness of Entrepreneurial Orientation. Entrepreneurship Theory and Practice, 35, 895-923.

WALTER, A., AUER, M. \& RITTER, T. 2006. The impact of network capabilities and entrepreneurial orientation on university spin-off performance. Journal of Business Venturing.

WHITEHEAD, K. K., ZACHARIA, Z. G. \& PRATER, E. L. 2016. Absorptive capacity versus distributive capability. International Journal of Operations \& Production Management, 36, 1308-1332.

WIKLUND, J. \& SHEPHERD, D. 2005. Entrepreneurial orientation and small business performance: a configurational approach. Journal of Business Venturing, 20, 71-91.

WILHELM, M. \& SYDOW, J. 2018. Managing Coopetition in Supplier Networks - A Paradox Perspective. Journal of Supply Chain Management, 54, 22-41.

ZACHARIA, Z. G., NIX, N. W. \& LUSCH, R. F. 2011. Capabilities that enhance outcomes of an episodic supply chain collaboration. Journal of Operations Management, 29, 591-603.

ZAHRA, S. \& GEORGE, G. 2002. Absorptive capacity: a review, reconceptualization, and extension. Academy of Management review, 27, 185-203.

ZAHRA, S. A. 1993. Environment, corporate entrepreneurship, and financial performance: A taxonomic approach. Journal of Business Venturing, 8, 319-340.

ZAHRA, S. A. \& COVIN, J. G. 1995. Contextual influences on the corporate entrepreneurshipperformance relationship: A longitudinal analysis. Journal of Business Venturing, 10, 43-58.

\section{Figure 1: Conceptual model and summarised results}

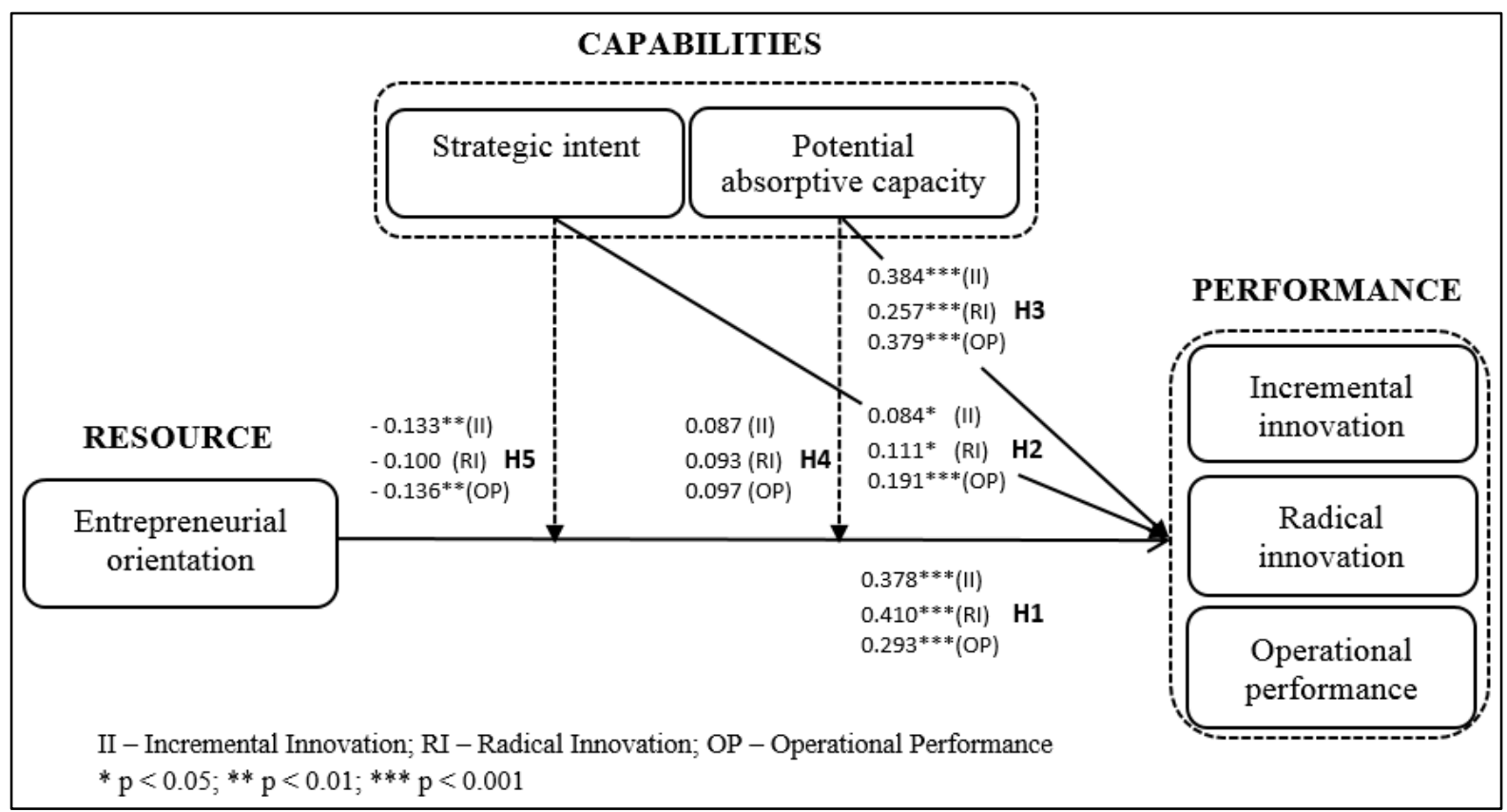




\section{Figure 2: Moderating effects of SI and PAC on EO-Performance relationships}

OPERATIONAL PERFORMANCE

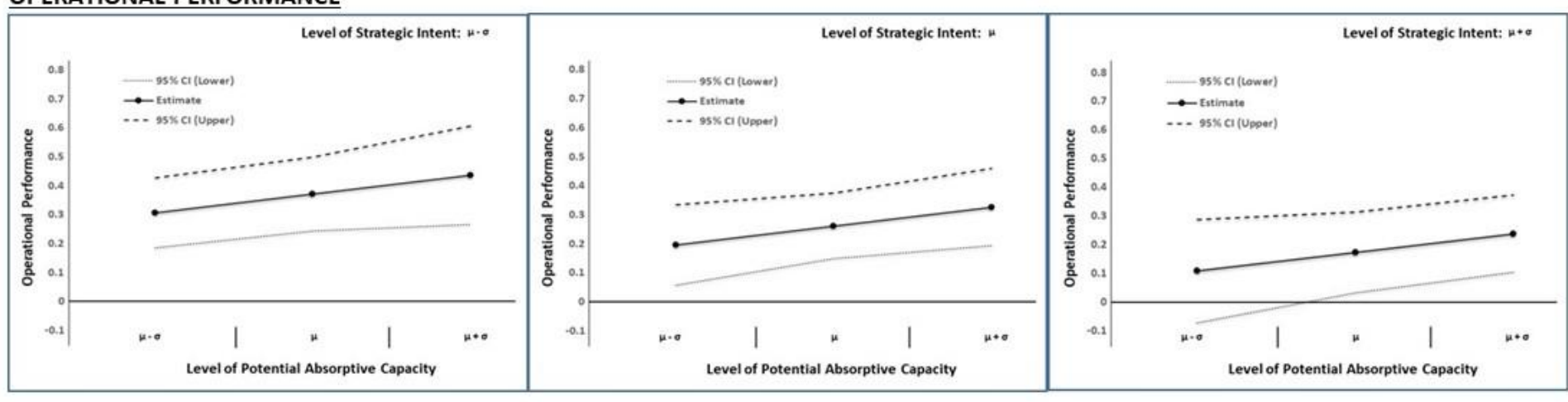

INCREMENTAL INNOVATION

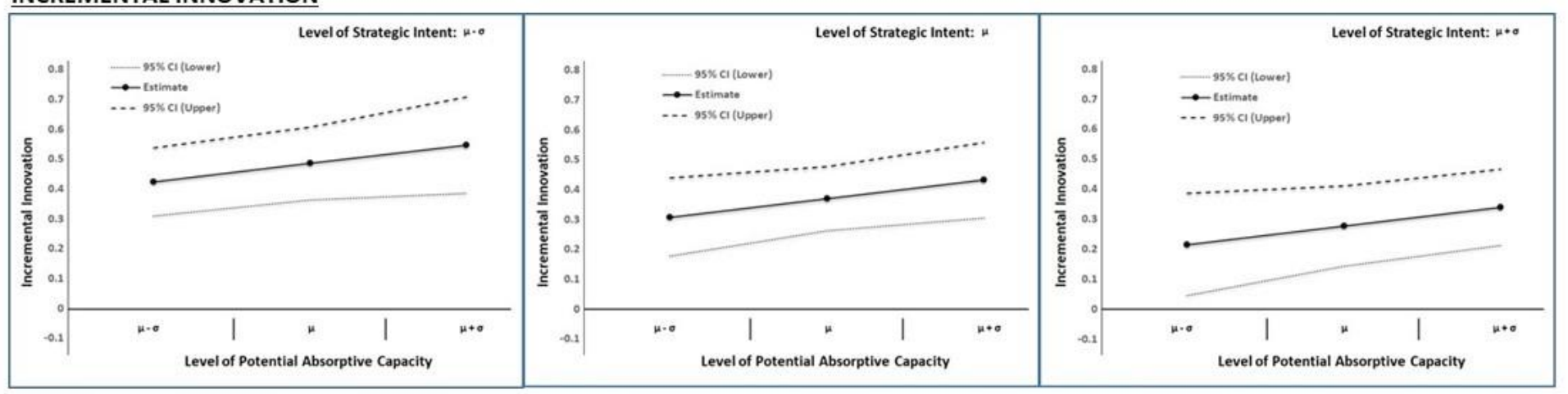

RADICAL INNOVATION

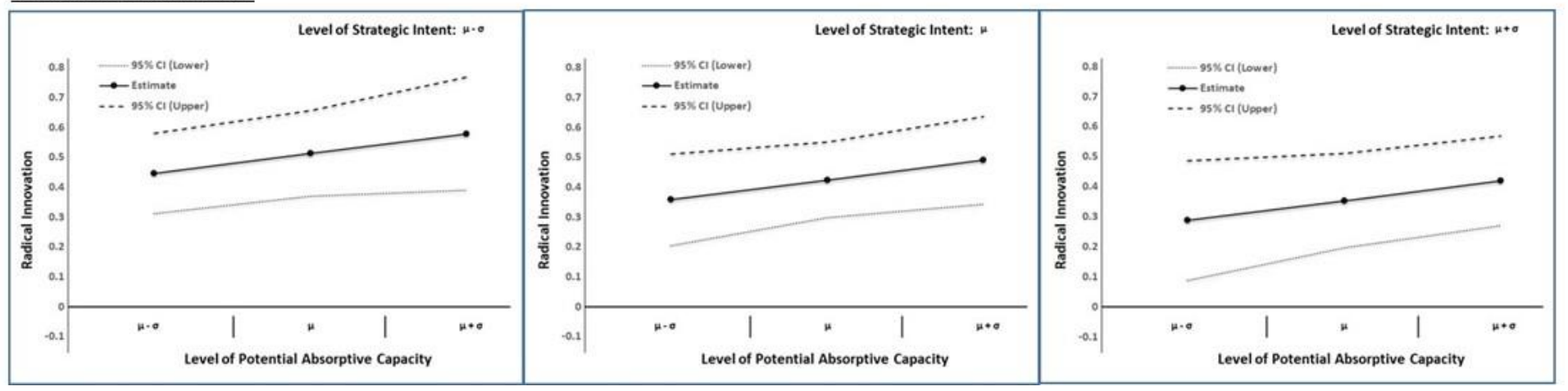


Table 1: Overview of sample characteristics

\begin{tabular}{|ll|}
\hline & Share (\%) \\
\hline Firm Characteristics & \\
Number of employees & \\
$51-250$ & 33.9 \\
$251-1000$ & 41.9 \\
1001 and above & 24.3 \\
Company age (in years) & \\
$1-5$ & 0.6 \\
6-10 & 17.9 \\
$11-20$ & 34.8 \\
20 and above & 46.6 \\
Industry & \\
Automobiles/Automotive & 11.5 \\
Consumer electronics & 6.4 \\
Engineering & 28.4 \\
Information and communication technology (ICT) & 29.7 \\
Machinery & 12.5 \\
Pharmaceuticals & 6.4 \\
Research and Development (R\&D) & 5.1 \\
Respondent characteristics & \\
Position within the company (Title) & \\
Alliance manager & 3.2 \\
CEO/COO/CFO/CTO & 20.1 \\
General manager & 15.7 \\
Managing director & 16.0 \\
Product manager & 28.4 \\
R\&D manager & 9.9 \\
Vice president & 6.7 \\
Years of employment in current position & 31.6 \\
2-5 6-10 & 39.3 \\
11-20 & 21.1 \\
20 and above & 8.0 \\
\hline
\end{tabular}


Table 2: Correlations

\begin{tabular}{|lllllllll|}
\hline Factors & Mean & S.D & EO & PAC & SI & OO & II & RI \\
EO & 5.484 & 0.981 & 1 & & & & & \\
PAC & 5.666 & 0.985 & 0.695 & 1 & & & & \\
SI & 5.282 & 1.127 & 0.562 & 0.493 & 1 & & & \\
OO & 5.647 & 0.970 & 0.672 & 0.690 & 0.544 & 1 & & \\
II & 5.605 & 1.039 & 0.743 & 0.746 & 0.523 & 0.714 & 1 & 1 \\
RI & 5.469 & 1.054 & 0.704 & 0.644 & 0.497 & 0.664 & 0.767 & 1 \\
\hline
\end{tabular}

$\mathrm{N}=313$;

All correlations are significant at $\mathrm{p}<0.01$

Table 3: Regression - Direct and interaction effects

\begin{tabular}{|c|c|c|c|c|c|c|}
\hline & \multicolumn{2}{|c|}{ Operational performance } & \multicolumn{2}{|c|}{ Incremental Innovation } & \multicolumn{2}{|c|}{ Radical Innovation } \\
\hline$\underline{\text { Control variables }}$ & Model 1 & Model 2 & Model 3 & Model 4 & Model 5 & Model 6 \\
\hline Employee size & -0.040 & -0.042 & -0.009 & -0.010 & -0.078 & $-0.082^{*}$ \\
\hline Company age & -0.055 & -0.051 & -0.050 & -0.047 & -0.052 & -0.049 \\
\hline Relationship length & -0.022 & -0.015 & 0.017 & 0.023 & 0.074 & 0.078 \\
\hline $\begin{array}{ll}\text { Amount of } & \text { R\&D } \\
\text { collaboration } \\
\text { Amount of New }\end{array}$ & $0.122^{*}$ & $0.134^{*}$ & -0.003 & 0.007 & 0.110 & $0.123 *$ \\
\hline $\begin{array}{l}\text { Product Development } \\
\text { (NPD) }\end{array}$ & -0.017 & -0.034 & 0.043 & 0.028 & -0.038 & -0.056 \\
\hline $\begin{array}{l}\text { Amount of technology } \\
\text { development }\end{array}$ & -0.066 & -0.066 & 0.072 & 0.072 & 0.053 & 0.054 \\
\hline Country & 0.008 & 0.009 & -0.007 & -0.006 & -0.028 & -0.030 \\
\hline$\underline{\text { Predictor }}$ & & & & & & \\
\hline $\mathrm{EO}$ & $0.293^{* * * *}$ & $0.286^{* * * *}$ & $0.378^{* * * *}$ & $0.370^{* * *}$ & $0.410^{* * * *}$ & $0.408 * * *$ \\
\hline SI & $0.191 * * *$ & $0.179 * \cdots *$ & $0.084^{*}$ & 0.073 & $0.111^{*}$ & $0.101^{*}$ \\
\hline PAC & $0.379 * * *$ & $0.407 * * *$ & $0.384 * * *$ & $0.409 * * *$ & $0.257 * * *$ & $0.286^{* * * *}$ \\
\hline $\mathrm{SI} * \mathrm{EO}$ & & $-0.136^{* *}$ & & $-0.133^{* *}$ & & -0.100 \\
\hline $\mathrm{PAC} * \mathrm{EO}$ & & 0.097 & & 0.087 & & 0.093 \\
\hline$\underline{\text { Model summary }}$ & & & & & & \\
\hline $\mathrm{R}^{2}$ & 0.571 & 0.581 & 0.664 & 0.673 & 0.563 & 0.569 \\
\hline Adjusted $\mathrm{R}^{2}$ & 0.556 & 0.564 & 0.652 & 0.660 & 0.548 & 0.551 \\
\hline Model F-value & $39.097 * * *$ & $33.704 * * *$ & $58.023 * * *$ & $50.151^{* * * *}$ & $37.888 * * *$ & $32.102^{* * * *}$ \\
\hline
\end{tabular}




\section{Appendix}

\section{Factor analysis results}

Entrepreneurial orientation $(\alpha=0.804 ; \Omega=0.806 ; \mathrm{AVE}=0.52 ; \mathrm{CR}=0.81$ )

Loadings

A strong emphasis on $R \& D$, technological leadership, and innovation.

A strong tendency for high-risk projects which have a chance of very high returns*.

A tendency to initiate actions that competitors respond to.

A tendency to be a leader, always introducing new products, service or technology first.

0.819

A tendency to adopt a competitive 'undo-the-competitors' posture.

0.647

Potential absorptive capacity $(\alpha=0.788 ; \Omega=0.792 ; \mathrm{AVE}=0.56 ; \mathrm{CR}=0.79$ )

We can identify and quickly acquire the information we need*.

We try to acquire new information in our company as soon as it is available. $\quad 0.690$

We constantly try to increase the number of our information sources.

$\begin{array}{ll}\text { We have invested heavily in acquiring new information. } & 0.808\end{array}$

Strategic intent $(\alpha=0.857 ; \Omega=0.860 ; \mathrm{AVE}=0.61 ; \mathrm{CR}=0.86)$

Is strategically aggressive.

Seeks competitive dominance.

0.828

$\begin{array}{ll}\text { Focuses on ambitious strategic targets and goals. } & 0.799\end{array}$

$\begin{array}{ll}\text { Focuses attention of winning in the market place. } & 0.734\end{array}$

Incremental innovation ( $\alpha=0.848 ; \Omega=0.849 ; \mathrm{AVE}=0.65 ; \mathrm{CR}=0.85$ )

Estimate the extent of the following benefits this relationship has brought to 'your company' in the past 3-5 years ....

Improving current products/services/processes.

Percentage of total sales from improved current products/services is up substantially.

Percentage of improved current products/services in the product range is significantly

higher compared to the competitors.

Radical innovation $(\alpha=0.795 ; \Omega=0.796 ; \mathrm{AVE}=0.56$; $\mathrm{CR}=0.79$ )

Estimate the extent of the following benefits this relationship has brought to 'your company' in the past 3-5 years ...

Creating completely new products/services/processes.

0.711

Percentage of total sales from completely new products/services is up substantially.

Percentage of completely new products/services in the product range is significantly

higher compared to the competitors

Operational outcomes $(\alpha=0.849 ; \Omega=0.850 ; \mathrm{AVE}=0.54 ; \mathrm{CR}=0.85)$

This relationship has resulted in ...

Reduced costs.

$\begin{array}{lr}\text { Increased efficiency. } & 0.772\end{array}$

$\begin{array}{lr}\text { Increased reliability. } & 0.837\end{array}$

$\begin{array}{lr}\text { Increased repeatability. } & 0.701\end{array}$

Increased quality*.

Increased flexibility.

0.711

*Items deleted due to having not met the psychometric requirements. 